\title{
Replication of Canine Herpesvirus
}

\author{
II. Virus Development and Release in Infected Dog Kidney Cells
}

\author{
JOHN D. STRANDBERG AND LAURE AURELIAN \\ Departments of Pathology, Microbiology, and Laboratory Animal Medicine, The Johns Hopkins University \\ School of Medicine. Baltimore, Maryland 21205
}

Received for publication 29 July 1969

\begin{abstract}
The studies reported in this paper demonstrate that, although canine herpesvirus differs from other herpesviruses in that it is characterized by a restricted host range, the pattern of virus development in the permissive host closely resembles that previously described for herpes simplex virus. These experiments also reveal the formation in the infected dog kidney cells of a system of tubules and channels in which virions accumulate. It is suggested that these membrane-bound structures serve to protect enveloped virus from being uncoated in the cytoplasm and function in virus release from the infected cells.
\end{abstract}

Recently, a virus designated canine herpesvirus (CHV) has been isolated from neonatal and fetal pups suffering from a fatal septicemic disease $(5$, 21). The virus has been shown to be morphologically similar to the herpesviruses $(21,22)$, to contain DNA (6), and to grow only in dog kidney cells (21).

The restricted host range of $\mathrm{CHV}$ has led to speculation as to the similarity in biological and developmental properties between CHV and other members of the herpesvirus group characterized by a rather wide host range such as herpes simplex virus.

The present studies indicate that the sequence of development of $\mathrm{CHV}$ in its permissive host, i.e., dog kidney (DK) cells, is approximately identical to that reported for other herpesviruses; however, virus is released from the infected cells via a pathway of tubules and channels, a process different from that previously described for most herpesviruses.

\section{MATERIALS AND METHODS}

Solutions and media. The solutions and media used were the same as those described in the first paper of this series (3).

Virus. The F205 strain of canine herpesvirus $(5,22)$, the pertinent properties of which have been described $(1-3,22)$, was originally obtained from L. E. Carmichael, Cornell University, Ithaca, N.Y.

Cells. DK cells, a line maintained in this laboratory since 1963, were grown to confluency in 250-ml Falcon plastic flasks.

Cell infection. Monolayers of DK cells containing $10^{6}$ to $2 \times 10^{6}$ cells were exposed to 5 to 10 plaqueforming units (PFU) of CHV per cell. After $1 \mathrm{hr}$ at $37 \mathrm{C}$, the monolayers were washed with PBS-A and overlaid with $\mathbf{M}-\mathbf{M}$ (maintenance medium; 3 ). At intervals indicated in Table 1, two cultures were removed for virus titration and electron microscopy. Virus assays were performed by a method previously described (1), and titers are expressed in terms of PFU/cell.

Electron microscopy. The cells were scraped and centrifuged at $400 \times g$ for $5 \mathrm{~min}$. The resulting pellets were fixed for $1 \mathrm{hr}$ in $4 \%$ glutaraldehyde, washed, fixed in $1 \%$ osmium tetroxide for 30 min, dehydrated, and embedded in Araldite 6005. Sections were cut on a Porter-Blum MT-2 ultramicrotome, stained with uranyl acetate and lead citrate, and examined in a RCA EMU-3G electron microscope.

\section{RESULTS}

Pattern of virus development. The earliest sign of infection, detected at $3 \mathrm{hr}$ was an increase in the number and prominence of polyribosomes in the cytoplasm of the infected cells (Fig. 1) as compared to the uninfected (Fig. 2). As summarized in Table 1, virions were not observed at this stage. By the fifth hour, intranuclear coreless capsids or capsids containing pleomorphic cores of low density (Fig. 3) were found in 1 to $2 \%$ of the cells. A few capsids already possessed electron-dense cores (Fig. 4). With time after infection, the number of particles containing electron opaque cores increased; however intranuclear particles, coreless and with cores of low density, were observed throughout the reproductive cycle. Crystalline arrays of intranuclear capsids were not detected. Concomitantly, nuclear alterations appeared and consisted of irregularity of the nuclear outline, widening of the perinuclear space, irregular condensation and margination of nuclear chromatin and formation of round, electron-opaque bodies at the nuclear membrane (Fig. 5-8). Occasionally virus was found in association with these dense bodies (Fig. 4). 
TABLE 1. Relative numbers of different forms encountered at sequential intervals after infection

\begin{tabular}{|c|c|c|c|c|c|c|c|}
\hline \multirow{2}{*}{$\begin{array}{l}\text { Time (hr) } \\
\text { after } \\
\text { inoculation }\end{array}$} & \multicolumn{7}{|c|}{ Virus types and location } \\
\hline & $\begin{array}{l}\text { Intranuclear } \\
\text { capsids } \\
\text { without } \\
\text { dense cores }\end{array}$ & $\begin{array}{l}\text { Intranuclear } \\
\text { capsids with } \\
\text { dense cores }\end{array}$ & $\begin{array}{l}\text { Cytoplasmic } \\
\text { unenveloped } \\
\text { capsids }\end{array}$ & $\begin{array}{l}\text { Intracellular } \\
\text { enveloped } \\
\text { capsids }\end{array}$ & $\begin{array}{l}\text { Extracellular } \\
\text { enveloped } \\
\text { capsids }\end{array}$ & $\begin{array}{l}\text { Per cent } \\
\text { cells } \\
\text { containing } \\
\text { virus }\end{array}$ & $\begin{array}{l}\text { Virus titer } \\
\text { (PFU/cell) }\end{array}$ \\
\hline 0 & 0 & 0 & 0 & 0 & 0 & 0 & Not tested \\
\hline 3 & 0 & 0 & 0 & 0 & 0 & 0 & $<0.1$ \\
\hline 5 & + & \pm & 0 & 0 & 0 & $1-2$ & $<0.1$ \\
\hline 7 & ++ & $+\overline{+}$ & + & + & 0 & 5 & 0.5 \\
\hline 9 & +++ & +++ & ++ & ++ & + & 20 & 1.0 \\
\hline 11 & +++ & $++t$ & +++ & +++ & ++ & 50 & 6.0 \\
\hline 15 & $+t$ & ++ & $+t+$ & $++t$ & $++t$ & 85 & 30 \\
\hline 24 & ++ & ++ & $++t$ & +++ & $++t+$ & 98 & 105 \\
\hline
\end{tabular}

Alterations in the nuclear membrane were detected at $7 \mathrm{hr}$ together with the appearance of enveloped particles. They consisted of reduplication of the inner lamella of the nuclear membrane (Fig. 11), of invagination of the lamella with formation of apparent intranuclear vesicles (Fig. 7), and of the proliferation of both inner and outer lamellae to form nuclear lobes extending into the cytoplasm (Fig. 12). Nucleocapsids were occasionally observed in apposition to and partially surrounded by modified nuclear membrane, suggesting they were in the process of being enveloped (Fig. 14). Enveloped particles accumulated in the intranuclear vesicles (Fig. 7), the widened perinuclear space (Fig. 8), in cytoplasmic membrane-bound structures (Fig. 9, 19, 20) and occasionally in the nuclear lobes (Fig. 12). Of particular interest is the observation that, whereas nucleocapsids could be detected free in the cytoplasm (Fig. 6), enveloped particles were found only in membrane-bound compartments.

The ninth hour of infection was characterized by the appearance of enveloped particles in the extracellular space (Fig. 10) and the modification of the membranes of the Golgi system. Partially enveloped capsids were seen in association with these membranes (Fig. 15), whereas fully enveloped particles were found in elongated membrane-bound structures (Fig. 19-22). Between 7 and $9 \mathrm{hr}$, in cells containing enveloped virus, there was a breakdown in the large polyribosomes observed up to this time, with accumulation of many individual ribosome-like particles (Fig. 2).

An increased number of virions at any of the stages described, the appearance in the nuclear matrix of many electron-dense granules and bundles of filaments, and focal breakage of the nuclear membrane were seen in the late hours of infection (Fig. 5).

Virus release. Small tubules became apparent at $9 \mathrm{hr}$ after infection of DK cells with CHV (Fig.
16). The membranes limiting these tubules were continuous at one end with the outer lamella of the nuclear membrane, and they extended into the cytoplasm for varying distances (Fig. 17). At $9 \mathrm{hr}$, enveloped nucleocapsids appeared at the junction of the tubules with the perinuclear space (Fig. 18). In the later stages of infection, 15 to $24 \mathrm{hr}$, intact tubules were not seen. Instead enveloped nucleocapsids seemed to accumulate in enlarged channel-like membrane-bound structures (Fig. 21). Figure 22 illustrates the junction of these channels with the plasma membrane and resulting release of virus.

\section{DISCUSSION}

The restricted host range of $\mathrm{CHV}$ has led to speculation as to its pattern of replication in the permissive host. Close resemblance between $\mathrm{CHV}$ and other members of the herpesvirus group (7, $10,13)$, particularly herpes simplex virus $(7,11$, $13,19)$ to which it is immunologically related $(1)$, was reported. The results obtained merit discussion from thestandpoint of virus formation as well as the problems relating to virus release.

Virus development. The morphological manifestation of the development of CHV correlates well with the pattern of synthesis of virus components $(2,3)$. Protein synthesis required for DNA duplication takes place between 0 and 3.5 to $4 \mathrm{hr}$ after infection (3). Accordingly, virus particles are not seen during this time (Table 1); the main feature of this phase is an increase in the number of cytoplasmic polyribosomes over those in uninfected cells (Fig. 1). Between 4 and $6 \mathrm{hr}$, synthesis of virus DNA (3) and antigen (Aurelian, unpublished data) becomes apparent. Correspondingly, intranuclear immature virus particles first appear during this phase; 5 to $10 \%$ of these particles already contain DNA (8), suggesting that nucleocapsid formation is a rapid process, probably one of self-assembly (4). 

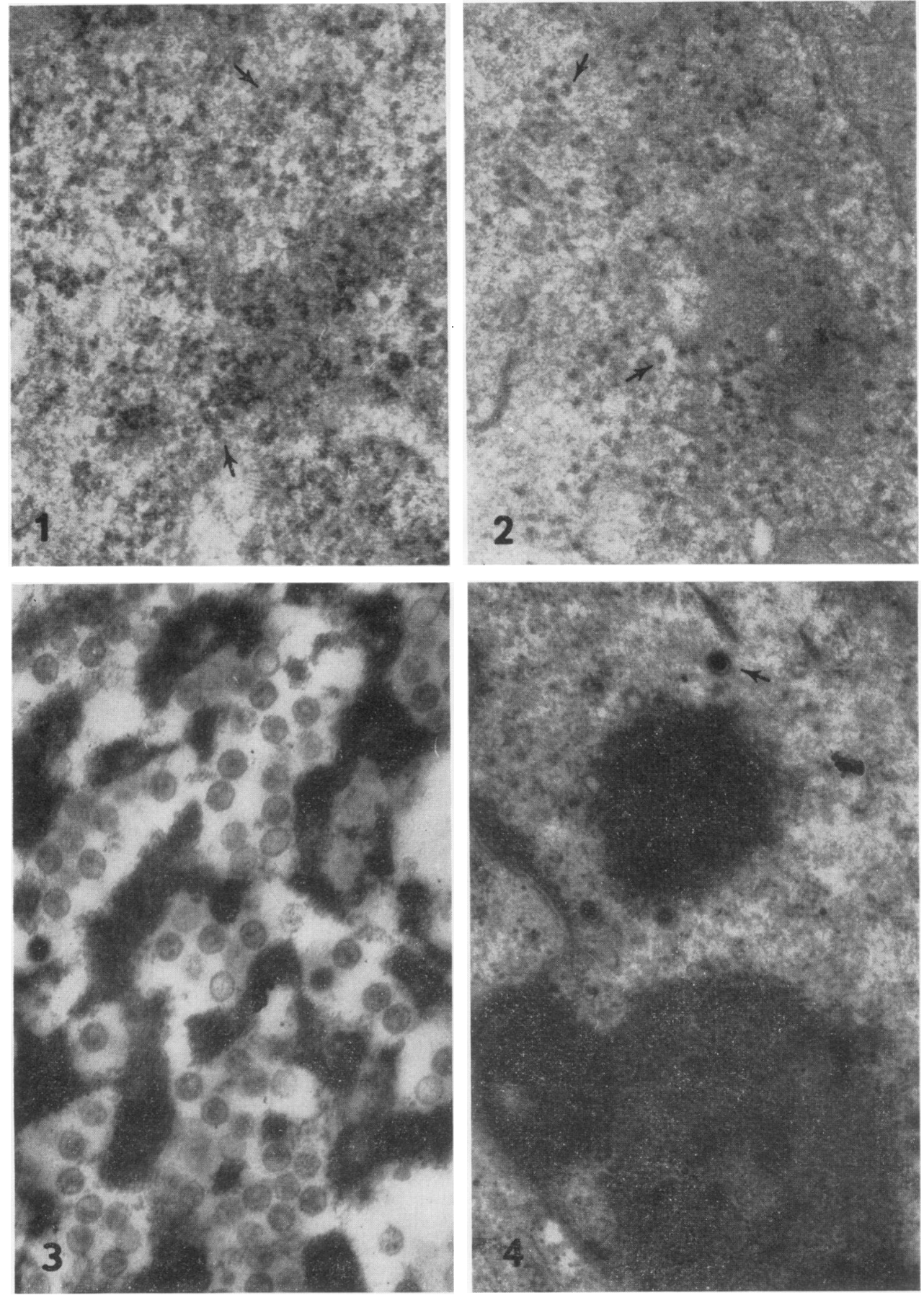

FIG. 1. Polyribosomes (arrow) in the cytoplasm of a cell at $3 \mathrm{hr}$ after infection. $\times 90,000$.

FIG. 2. Cytoplasm of a cell $9 \mathrm{hr}$ after infection showing scattered ribosomelike particles (arrows). $\times 90,000$.

FIG. 3. Pleomorphic intranuclear capsids. $\times 43,300$.

FIG. 4. Viral capsids, with electron-dense cores (arrow), associated with intranuclear electron-dense bodies. $\times 43,000$ 

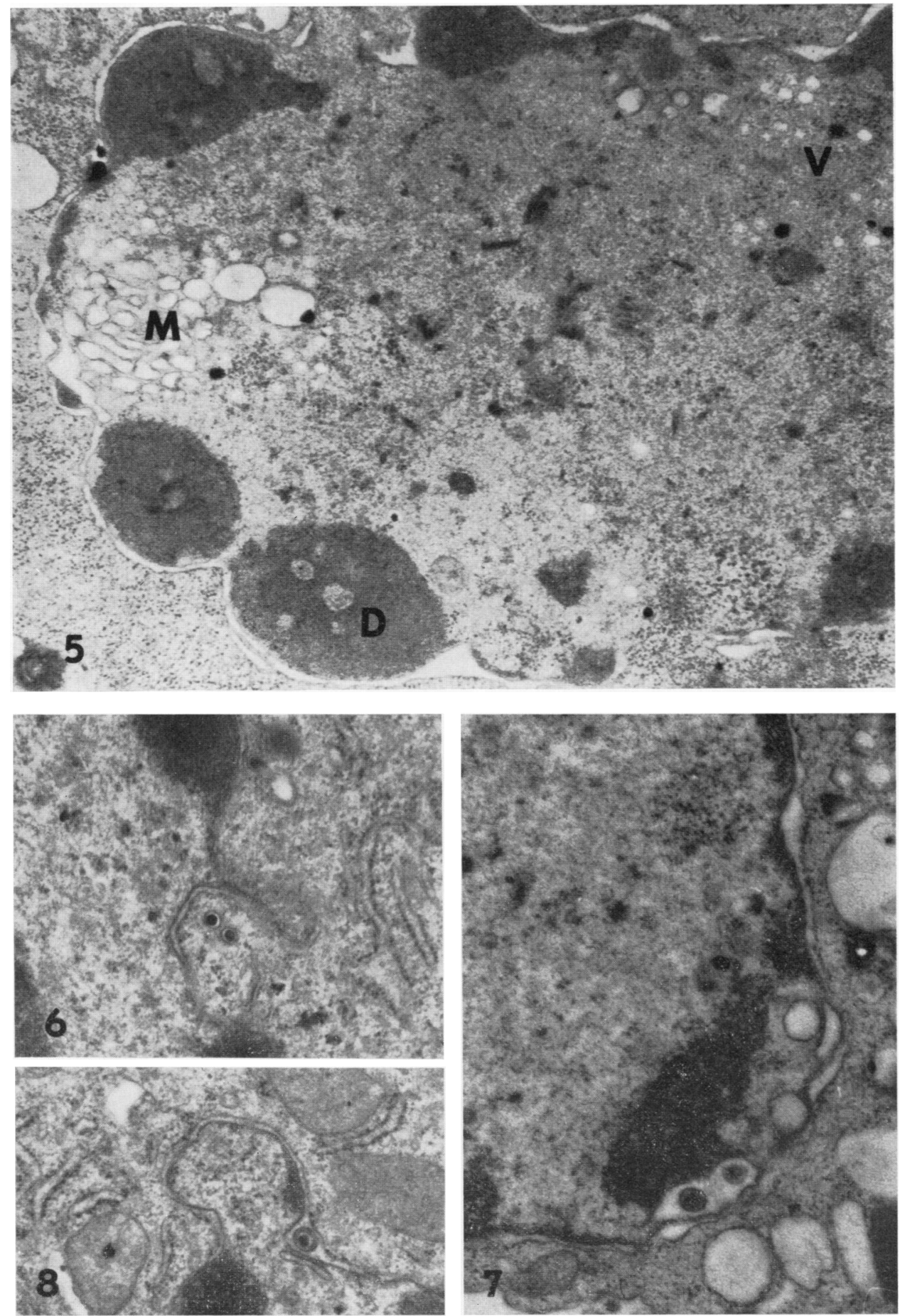

Fig. 5. Cell, $11 \mathrm{hr}$ after infection, with intranuclear capsids $(V)$ and nuclear alterations including dense bodies $(D)$, membranous proliferation $(M)$, and small bundles of filaments. In the lower right there is breakdown of the nuclear membrane. $\times 18,200$.

Fig. 6. Unenveloped p.trticles in th? cytoplasin. $\times 32,000$.

FIG. 7. Enveloped capsids in "vesicles" formed at the inner lamella of the nuclear membrane. $\times 32,000$.

FIG. 8. Enveloped virus in the perinuclear space. $\times 32,000$. 

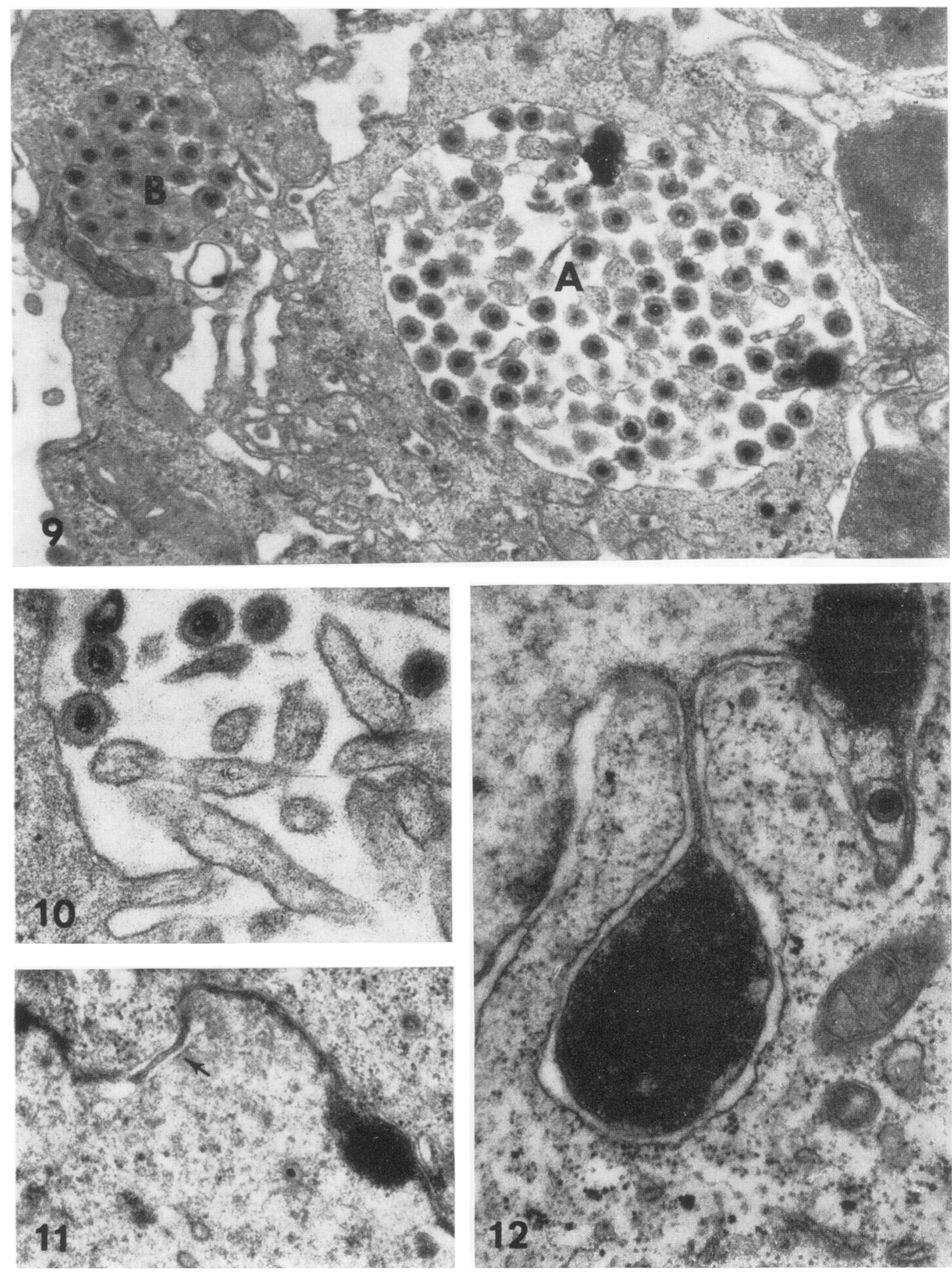

FIG. 9. Virus in cytoplasmic compartments. The larger $(A)$ which is bounded by a complete membrane contains intact virions along with cellular debris. The smaller $(B)$ has an incomplete membrane and the particles within it are partially uncoated. $24 \mathrm{hr} . \times 33,200$.

FIG. 10. Extracellular virus with typical herpesvirus morphology. $\times 55,700$.

FIG. 11. Reduplication of the inner lamella of the nuclear membrane (arrow). At $7 \mathrm{hr}$ after infection. $\times 35,800$.

Fig. 12. Extensions of lobes of the nucleus into the cytoplasm. At $7 \mathrm{hr}$ after infection. $\times 40,000$. 

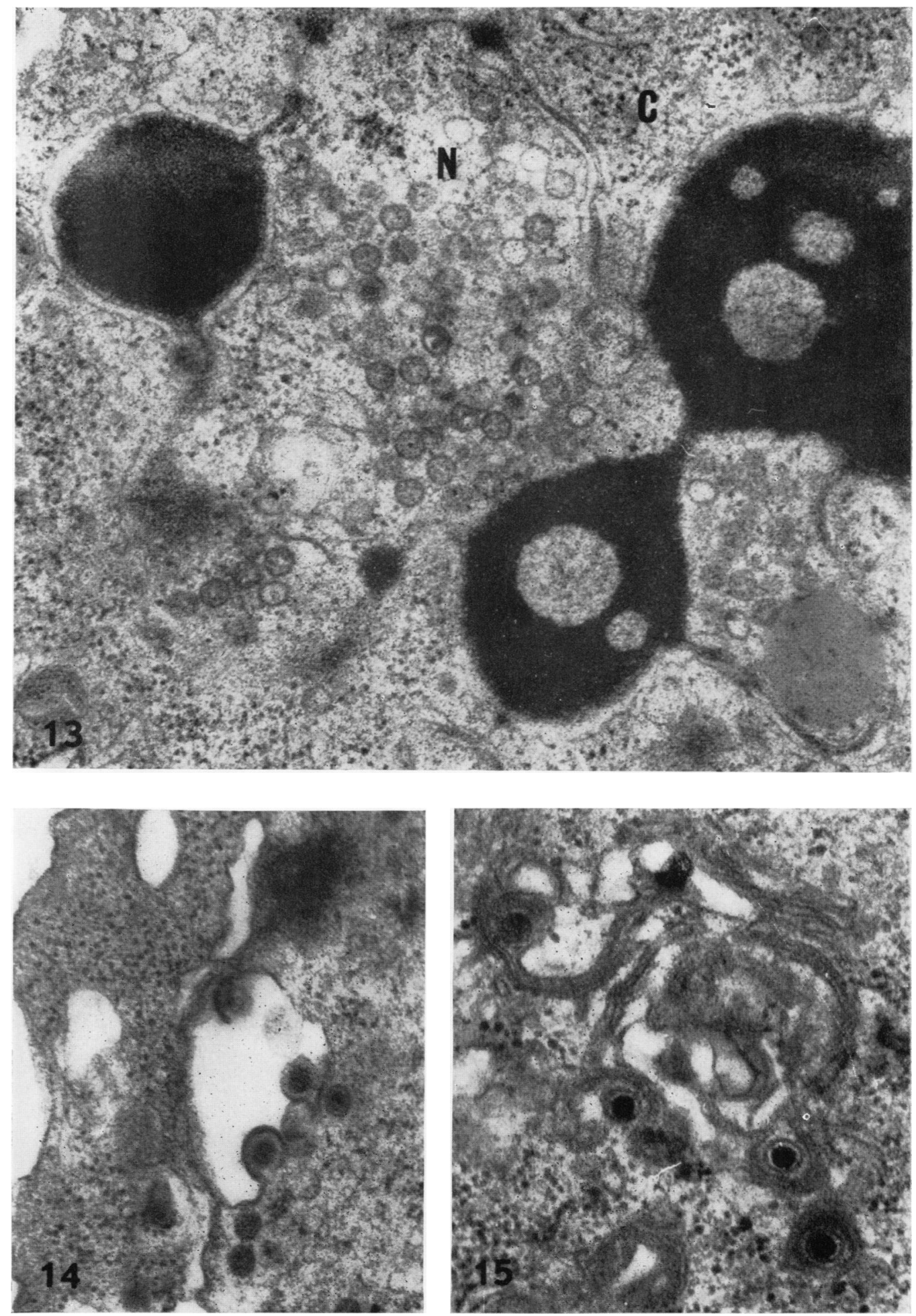

Fig. 13. Capsids in a lobe of the nucleus $(N)$. Note presence of characteristic nuclear dense bodies in this structure. Cytoplasm $(C)$. At $11 \mathrm{hr}$ after infection. $\times 54,100$.

FIG. 14. Virus "budding" through the inner nuclear membrane into a vesicular space at the nuclear periphery. $\times 54,100$.

FIG. 15. Golgi complex containing lamella arrangements of membranes, some associated with partially enveloped virions. $\times 64,000$. 

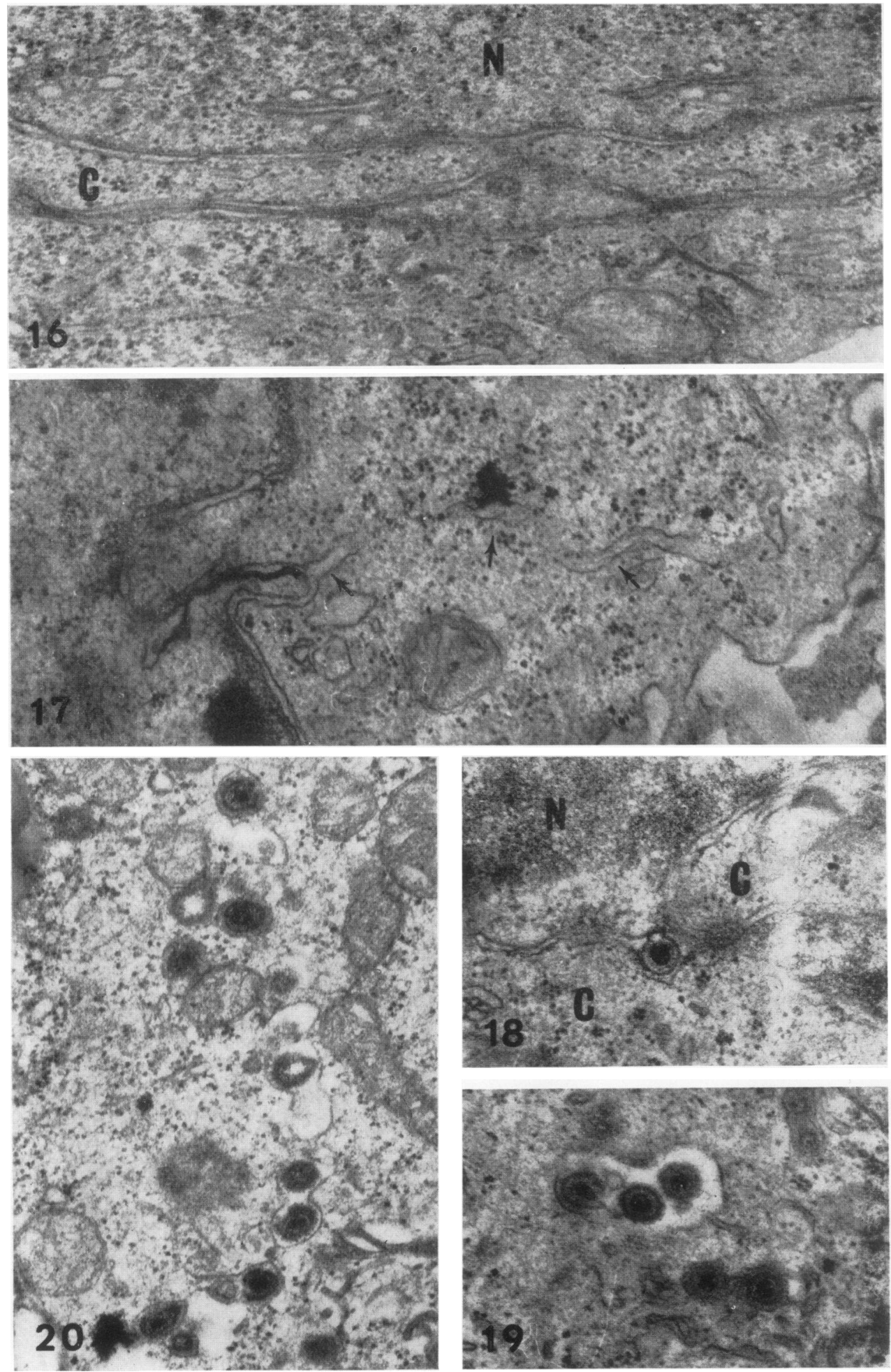

FIG. 16. Network of channels arising at the nuclear membrane extending into the cytoplasm $(C)$. Nucleus $(N)$. $\times 40,000$

FIG. 17. Undulating tubule arising from the outer nuclear membrane. The segments indicated by arrows are found connected in serial sections. $\times 40,000$.

Fig. 18. Enveloped virion in the perinuclear space at its junction with a tubule. Nucleus $(N)$, cytoplasm $(C)$. $\times 40,000$.

FIG. 19 and 20. Virions in channels in the cytoplasm. $\times 40,000$. 

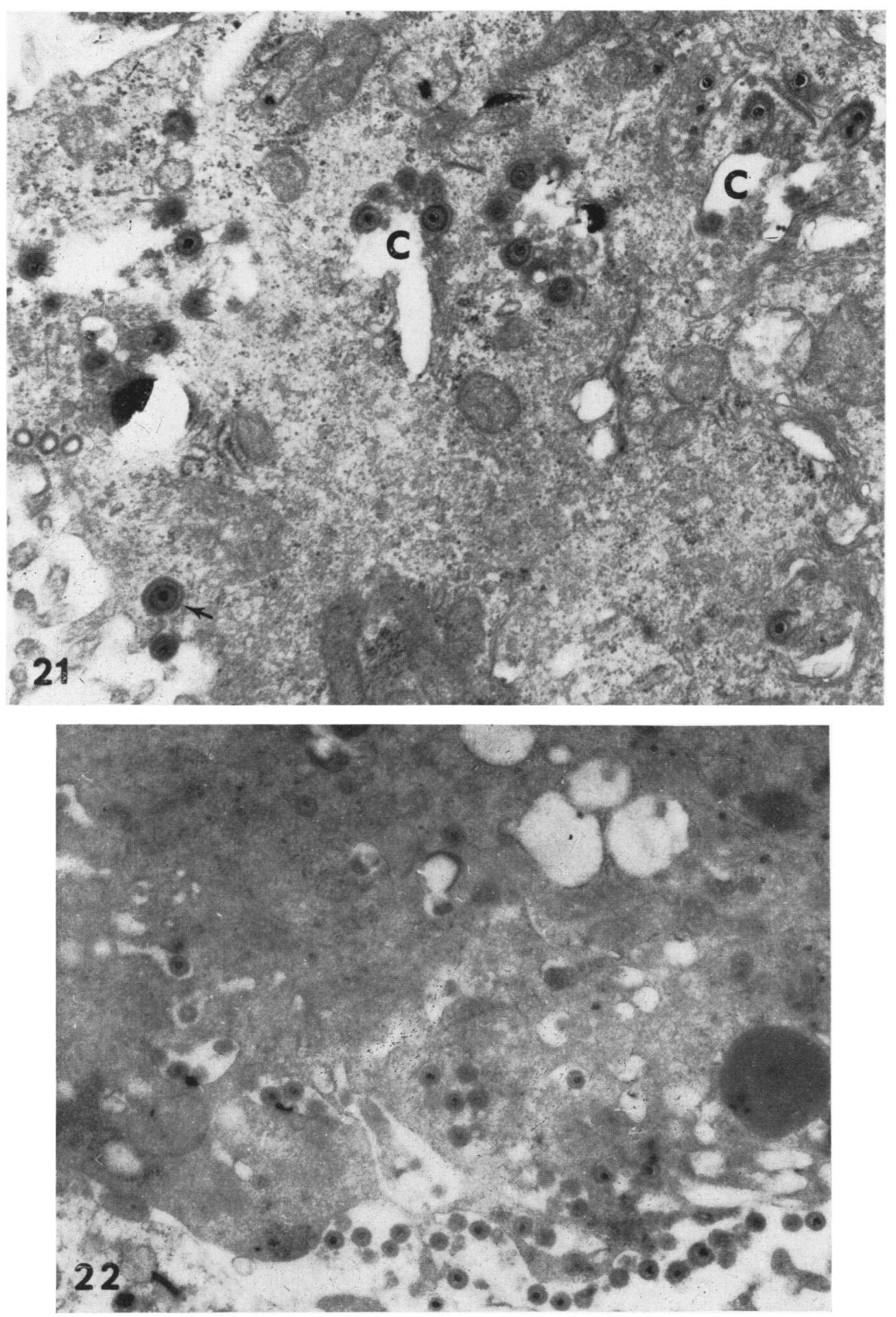

Fig. 21. Partially enveloped virus in the Golgi complex (upper and lower right) and complete virions in cytoplasmic compartments $(C)$ also containing membranous debris. The membrane surrounding the particle at the lower left (arrow) appears continuous with the plasma membrane. $\times 32,000$.

FIG. 22. Cytoplasmic compartments containing enveloped virus opening into the extracellular space (bottom). $\times 22,900$. 
Nuclescapsids acquire an envelope at the nuclear membrane as early as $7 \mathrm{hr}$ (Fig. 8). After this time asynchrony becomes apparent. This phase of the reproductive cycle previously characterized by an exponential increase in the amount of intracellular virus (2) is marked by an increase in the number of cells showing virus formation. Finally, after $24 \mathrm{hr}$, cell breakdown and fragmentation become evident providing an explanation for the substantial increase in virus release observed at this time (2).

Of particular interest is the observation that the polyribosome formations first detected at $3 \mathrm{hr}$ after infection show breakdown in cells actively accumulating enveloped virus ( 7 to $9 \mathrm{hr}$ ). This observation is in agreement with the findings of Roizman et al. (16) that in HEp-2 cells infected with herpes simplex virus there is a period of stimulated protein synthesis lasting between 2.5 and 8 $\mathrm{hr}$ after infection and coinciding with the aggregation and disaggregation of cytoplasmic polyribosomes (23).

Intranuclear crystalline arrays described for some members of the herpesvirus group (11) were not detected in CHV-infected DK cells. Crystal formation might be a property of the particular herpesvirus studied.

Virus release. Considerable disagreement still exists with regard to the mechanism of herpesvirus release from the infected cells. On one hand, Epstein (9) and Siminoff and Menefee (20) showed particles apparently "budding" from the cell surfaces, whereas, on the other hand, the presence of enveloped nucleocapsids in membranebound intracytoplasmic compartments similar to those seen in Figure 9 have led Nii et al. (13) to conclude that enveloped particles are contained in vacuoles and that virus is released by a process of reverse phagocytosis. Recently, Schwartz and Roizman (18) have presented evidence for the appearance of enveloped particles in membranebound tubules in HEp-2 cells infected with herpes simplex virus. They suggest that these tubules provide pathways for virus egress from the cell.

DK cells in the early stages of infection with CHV show features suggesting that a system of channels may play a role in virus release from the infected cell. Tubules continuous with the outer nuclear membrane and extending into the cytoplasm (Fig. 17) are not uncommon at this time. However, later in infection intact tubules are no longer detected, and virus is consistently found accumulating in channel-like, membrane-bound compartments of a considerably larger diameter and also partially enveloped in the Golgi area.

Several comments concerning the structure and function of tubules and channels as well as the release of virus are appropriate. (i) Tubules are not see $\mathrm{n}$ in uninfected DK cells. The source of the genetic information for their formation is unknown. Immunological (17) and electron microscopic (14) studies have established that nuclear and cytoplasmic membranes are altered after infection with herpes simplex virus, and acquire virus specificity. It may be that the tubules are actually a modification of a previously existing cytoplasmic structure such as the endoplasmic reticulum.

(ii) A priori it seems reasonable to assume that enveloped virus should not accumulate in the same cellular compartment in which virions are uncoated upon penetration. Indeed, Morgan et al. (12) indicated that uncoating occurs directly in the cytoplasm. Roizman (15) has shown that infected cells will uncoat a superinfecting virus for at least $6 \mathrm{hr}$ after infection with the first virus. It can be concluded that, for at least $6 \mathrm{hr}$ and perhaps longer, the cytoplasm is an unsuitable environment, in that virus accumulating in it will become uncoated. This hypothesis suggests that only virus inside membrane-bound cellular compartments would escape uncoating. The tubules provide such a compartment. Indeed, in HEp-2 cells infected with herpesvirus type 2 , in which intact tubules are infrequent, the cytoplasm is replete with unenveloped, partially disaggregated particles (Roizman, personal communication).

(iii) In the later stages of infection of DK cells with $\mathrm{CHV}$, tubules are no longer detected. Instead virions are observed accumulating in channels, i.e., membrane-bound compartments of larger diameter, as well as partially enveloped in the Golgi area (Fig. 15) or unenveloped throughout the cytoplasm (Fig. 6). It seems likely that the observation of partially enveloped virions in the Golgi has prompted some workers $(9,10,20)$ to conclude that virus can be enveloped also by membranes of this system; however, partially enveloped nucleocapsids can also represent virus in the process of uncoating and disaggregation. It may be that the channels represent the breakdown and coalescence of the tubules observed earlier in the replicative cycle. This would account for virus release into the cytoplasm with subsequent accumulation in the Golgi area and uncoating, and the presence of membranous debris in the channels (Fig. 21).

(iv) Finally, the tubules and channels could provide a pathway for virus release from the infected cells. Precisely how virus travels is not clear; it is probable that it is moved along by cell motility and contractions. The observation that extracellular virus is seen at the time that the tubules first appear suggests that tubules may provide a means for rapid release. Indeed, virions are seen accumulating only in the channels. 


\section{ACKNOWLEDG MENTS}

We are grateful for the excellent technical assistance of Miss Carole Heckner and Mrs. Y. Stein, and to Miss Johnnetta Perkins for help in preparing the manuscript.

This investigation was supported by Public Health Service grant FR.0013 from the Division of Research Facilities and Resources, by a grant from the Whitehall Foundation, and by U.S. Army Contract DA 18-064-ANC-104 (A) Task D.

\section{LITERATURE CITED}

1. Aurelian, L. 1968. Demonstration by plaque reduction technique of immunologic relationship between canine herpesvirus and herpes simplex virus. Proc. Soc. Exp. Biol. Med. 127:485-488.

2. Aurelian, L. 1969. Factors affecting growth of canine herpesvirus in dog kidney cells. Appl. Microbiol. 17: 179-181.

3. Aurelian, L. 1969. Replication of canine herpesvirus I. Synthesis of viral deoxyribonucleic acid. J. Virol. 4:197-202.

4. Bancroft, J. G., G. J. Hills, and R. Markham. 1967. A study of the self-assembly process in a small spherical virus. Formation of organized structures from protein subunits in vitro. Virology 31:354-379.

5. Carmichael, L. E., R. A. Squire, and L. Krook. 1965. Clinical and pathologic features of a fatal viral disease of newborn pups. Amer. J. Vet. Res. 26:803-814.

6. Carmichael, L. E., J. D. Strandberg, and F. D. Barnes. 1965 Identification of a cytopathogenic agent infectious for puppies as a canine herpesvirus. Proc. Soc. Exp. Biol. Med. 120:644-650.

7. Darlington, R. W., and L. H. Moss, III. 1968. Herpesvirus envelopment. J. Virol. 2:48-55.

8. Epstein, M. A. 1962. Observations on the fine structure of mature herpes simplex virus and on the composition of its nucleoid. J. Exp. Med. 115:1-12.

9. Epstein, M. A. 1962. Observations on the mode of release of herpesvirus from infected HeLa cells. J. Cell Biol. 12:589597.

10. McGavran, M. H., and M. G. Smith. 1965. Ultrastructural, cytochemical and microchemical observations on cytomegalovirus (salivary gland virus) infection of human cells in tissue culture. Exp. Mol. Pathol. 4:1-10.
11. Morgan, C., E. P. Jones, M. Holden, and H. M. Rose. 1958. Intranuclear crystals of herpes simplex virus observed with the electron microscope. Virology 5:568-571.

12. Morgan, C., H. M. Rose, and B. Mednis. 1968. Electron microscopy of herpes simplex virus. I. Entry. J. Virol. 2:507-516.

13. Nii, S., C. Morgan, and H. M. Rose. 1968. Electron microscopy of herpes simplex virus. II. Sequence of development. J. Virol. 2:517-536.

14. Nii, S., C. Morgan, H. M. Rose, and K. C. Hsu. 1968. Electron microscopy of herpes simplex virus. IV. Studies with ferritin-conjugated antibodies. J. Virol. 2:1172-1184.

15. Roizman, B. 1963. The programming of herpesvirus multiplication in doubly-infected and puromycin-treated cells. Proc. Nat. Acad. Sci. U. S. A. 49:165-171.

16. Roizman, B., G. S. Borman, and M. Kamali-Rousta. 1965. Macromolecular synthesis in cells infected with herpes simplex virus. Nature (London) 206:1374-1375.

17. Roizman, B., and S. B. Spring. 1967. Alteration in immunologic specificity of cells infected with cytolytic viruses, p. 85-96. In J. J. Trentin, Proc. Conf. Cross Reacting Antigens and Neoantigens. Williams and Wilkins, Co. Baltimore.

18. Schwartz, J., and B. Roizman. 1969. Concerning the egress of herpes simplex virus from infected cells: electron microscopic and light microscopic studies. Virology. 38:42-49.

19. Shipkey, F. H., R. A. Erlandson, R. B. Bailey, V. I. Babcock, and C. M. Southam. 1967. Virus biographies. II. Growth of herpes simplex virus in tissue culture. Exp. Mol. Pathol. 6:39-67.

20. Siminoff, P., and M. G. Menefee. 1966. Normal and 5-bromodeoxyuridine-inhibited development of herpes simplex virus. An electron microscope study. Exp. Cell Res. 44:241-255.

21. Stewart, S. E., J. David-Fereira, E. Lovelace, J. Landon, and N. Stock. 1965. Herpes-like virus isolated from neonatal and fetal dogs. Science 148:1341-1343.

22. Strandberg, J. D., and L. E. Carmichael. 1965. Electron microscopy of a canine herpesvirus. J. Bacteriol. 90:17901792.

23. Sydiskis, R. J., and B. Roizman. 1966. Polysomes and protein synthesis in cells infected with a DNA virus. Science 153: 76-78. 